\title{
にじます卵発生中の脂質の変化
}

\author{
安 藤 一 夫 \\ (1961 年 11 月 16 日受理)

\section{CHANGE OF THE LIPID DURING DEVELOPMENT OF RAINBOW TROUT EGGS}

\author{
Kazuo Ando*
}

\begin{abstract}
On eight stages of development of rainbow trout eggs as mentioned in Table 1, moisture, ash, total nitrogen, total lipid, acetone soluble and insoluble lipid were determined. Unsaponifiable matter, acid value, iodine value and mean molecular equivalent of fatty acid in the acetone soluble lipid were determined.

Results were;

(1) Variation of chemical compositions in the developing stages were practically equal to the SUYAMA's results (This journal Vol. 23, 785, 1958.)

(2) Decrease in acetone insoluble lipid during the developing process were found larger before hatching stage than after that stage. On the contrary acetone soluble lipid decreased after hatching stage more considerably than before that stage.

(3) Together with the development, the content of free fatty acid increased. The increase was remarkable on the last stage of the development.

(4) Iodine value of acetone soluble lipid were once decreased and then increased gradually.

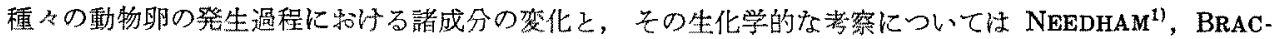
$\mathrm{KET}^{2)}$ らの綜述がある。魚類の発生沉ついての一般的な生化学的研究は, F. R. HAYES らをはじあとして数

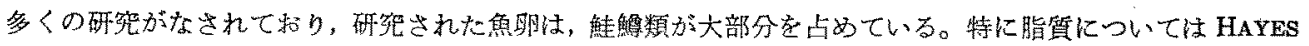

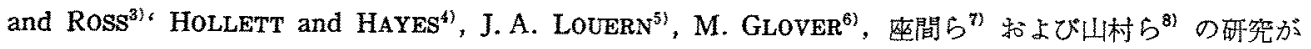
あるが，発生過程に推ける各段階を追及した研究は少ない。これら脂質についての報告を綜合すると，脂質

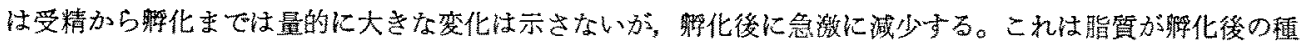
タのエネルギー源として重要なるのの一つである，と考えられている。また脂質構成についても，発生中に 撰択的な消耗あるいは蓄磧が予想されている。

著者はこの点を明らかにするために比較的試料の履歴の判つた，荃殖にじすす甽について実験を行なつた ので，その結果を報告する。
\end{abstract}

\section{試料および実験方法}

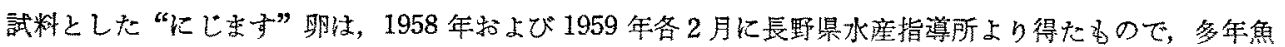

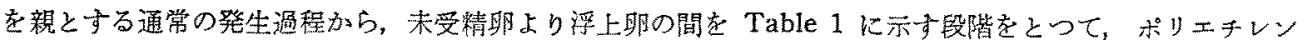

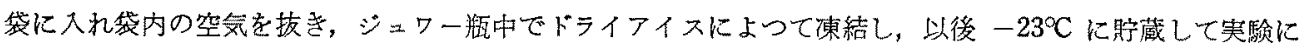
供した。分析値は雨年度の平均值である。

分析にあたつて，試料を垡の哀流水中で解谏し，内容物をすべてホモダナイザーで，乳泥状として，こ れを分析用試料とした。

* 東京水産大学 (Tokyo Univ. Fish., Shiba Kaigandori 6, Minato-ku, Tokyo). 
一般分析中，灭分は灰化法，全窒菜はケルダール法，水分，全脂質の测定は W.M. SPERY の方法にし

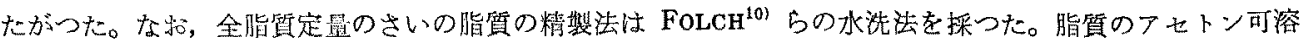
部と不溶部の分別定舅は次のごとくして行なつた。精製脂質をあらかじあ承冷した 20 倍墨のアせトンで処

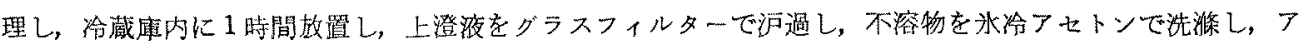
セトン可溶脂質を分離した。フをトン不溶脂質は，タロロホルムメタノール (2:1) 溶液で溶かし一定量と しその一部を蒸発乾燥して定量した。

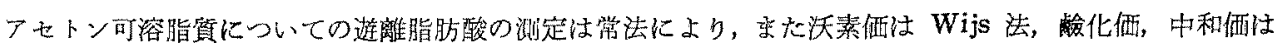

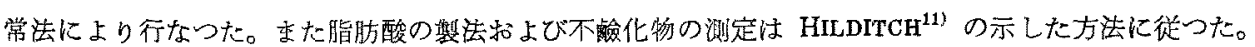

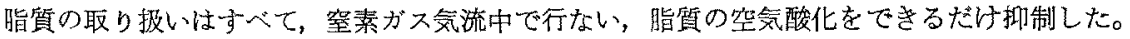

\section{実験結果および考繁}

（1）一般成分：一般成分の亲化はTable 1 中に示すよ 5 に，すでに須山 ${ }^{12)}$ が，同じく長野舆水産指導 所の卵について示した結果とほとんど同じ傾问を示している。

Table 1. Chemical analysis of the rainbow trout eggs during development.

\begin{tabular}{|c|c|c|c|c|c|c|c|c|c|}
\hline \multirow[b]{2}{*}{$\begin{array}{c}\text { Sample } \\
\text { No. }\end{array}$} & \multirow[b]{2}{*}{ Development stage } & \multirow{2}{*}{$\begin{array}{l}\text { Time } \\
\text { after } \\
\text { fertili- } \\
\text { zation } \\
\text { days }\end{array}$} & \multirow[b]{2}{*}{$\begin{array}{c}\text { Moisture } \\
\%\end{array}$} & \multirow[b]{2}{*}{$\begin{array}{l}\text { Ash } \\
\%\end{array}$} & \multirow{2}{*}{$\begin{array}{c}\text { Total } \\
\text { nitrogen } \\
\%\end{array}$} & \multirow{2}{*}{$\begin{array}{c}\text { Total } \\
\text { lipids. } \\
\%\end{array}$} & \multicolumn{2}{|c|}{$\begin{array}{l}\text { Acetone soluble } \\
\text { lipids. }\end{array}$} & \multirow{2}{*}{$\begin{array}{c}\text { Acetone } \\
\text { insoluble } \\
\text { lipids } \\
\%\end{array}$} \\
\hline & & & & & & & $\begin{array}{c}\text { Total } \\
\%\end{array}$ & $\begin{array}{l}\text { Unsapo- } \\
\text { nifiable } \\
\text { matter } \\
\%\end{array}$ & \\
\hline I & Unfertilized egg. & - & 59.27 & 1.58 & 4.62 & 11.81 & 8.28 & 0.66 & 3.53 \\
\hline II & Fertilized egg. & 9 & 64.12 & 1.31 & 4.09 & 9.85 & 7.24 & 0.58 & 2.61 \\
\hline III & Just before eye stage. & 13 & 64.01 & 1.33 & 4.08 & 9.37 & 7.36 & 0.58 & 2.01 \\
\hline IV & Eyed egg. & 19 & 64.08 & 1.39 & 4.21 & 8.95 & 7.06 & 0.53 & 1.89 \\
\hline $\mathrm{V}$ & Just before hatching. & 26 & 64.50 & 1.44 & 4.03 & 8.70 & 7.19 & 0.51 & 1.51 \\
\hline $\mathrm{VI}$ & Newly hatched fry. & 34 & 67.79 & 1.40 & 3.61 & 8.68 & 7.03 & 0.53 & 1.65 \\
\hline VII & $\begin{array}{l}\text { Fry. Absorbed } \\
\text { half yolk. }\end{array}$ & 47 & 75.93 & 1.11 & 2.58 & 6.43 & 5.03 & 0.29 & 1.40 \\
\hline VIII & Swim-up fry. & 58 & 79.68 & 1.21 & 2.15 & 4.43 & 3.21 . & 0.23 & 1.22 \\
\hline
\end{tabular}

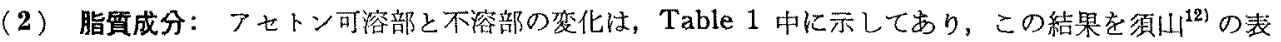
示法に従つて，未受精畉 $100 \mathrm{~g}$ 当りの $\mathrm{g}$ 数に换算した各成分の変化を Table 2 亿示す。この表より，全脂 質は瞬化末でに約 14\% 減少し，睬化後さらに約 40\% 在失ない，浮上時には末受精時の半分以下になる。

Table 2. Changes of lipid component $(g)$ equivalent to $100 \mathrm{~g}$ of unfertilized eggs during development.

\begin{tabular}{c|c|c|c|c|c}
\hline \hline Sample No. & Weight of eggs & Total lipids & \multicolumn{2}{|c|}{ Acetone soluble lipids } & $\begin{array}{c}\text { Acetone insoluble } \\
\text { lipids }\end{array}$ \\
\hline I & 100.0 & 11.81 & 8.28 & 0.66 & 3.53 \\
II & 117.1 & 11.53 & 8.48 & 0.66 & 3.05 \\
III & 116.6 & 10.93 & 8.36 & 0.66 & 2.57 \\
IV & 116.1 & 10.39 & 8.20 & 0.62 & 2.19 \\
V & 116.3 & 10.12 & 8.36 & 0.59 & 1.75 \\
VI & 104.4 & 9.06 & 7.34 & 0.55 & 1.72 \\
VII & 122.0 & 7.84 & 6.14 & 0.35 & 1.70 \\
III & 127.8 & 5.66 & 4.11 & 0.30 & 1.55 \\
\hline
\end{tabular}


アセトン可溶脂質は膘化まで若干の增減はあるが，ほとんど量的の恋化はなく，䊩化後に急激に減少する。 これに反して，アセトン不溶脂質は膰化まてに半減し，以後浮上までの減少は少ない。このアセトン不溶脂 質の変化については，他の文献では眀嘹な差が示されてはいないが，卵の繗脂質が受精によつて相当な影響

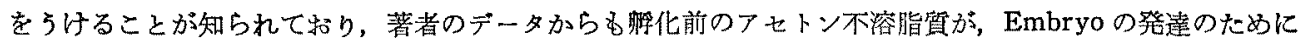
重要な役を演してていることが推察される。不羷化物の量は発生の初期には变化はほとんどなく，瞬化後に多 く消費される。これは山村 ${ }^{8)} ら の$ 鮭卵についての研究結果と一致している。

Table 3. Chemical properties of acetone soluble lipids and their fatty acids.

\begin{tabular}{c|c|c|c|c|c|c}
\hline \hline $\begin{array}{c}\text { Sample } \\
\text { No. }\end{array}$ & \multicolumn{3}{|c|}{ Acetone soluble lipids } & \multicolumn{3}{c|}{ Mixed fatty acids } \\
\cline { 2 - 7 } & Acid value & Iodine value & Sap. value & Iodine value & Neut. value & $\begin{array}{c}\text { Mean Mol. } \\
\text { Equivalent }\end{array}$ \\
\cline { 2 - 7 } I & 5.6 & 156.0 & 175.3 & 170.1 & 195.3 & 287.3 \\
II & 5.7 & 145.1 & 170.3 & 162.9 & 194.1 & 289.0 \\
III & 6.1 & 151.0 & 171.3 & 164.1 & 192.5 & 291.4 \\
IV & 7.5 & 159.0 & 173.0 & 172.1 & 192.9 & 290.8 \\
V & 9.1 & 159.1 & 170.1 & 176.8 & 192.4 & 291.6 \\
VI & 14.3 & 161.5 & 172.3 & 179.7 & 192.7 & 291.2 \\
VII & 25.6 & 164.9 & 170.3 & 184.9 & 194.1 & 289.1 \\
VIII & 42.5 & 174.4 & 172.3 & 194.1 & 194.4 & 288.6 \\
\hline
\end{tabular}

（3）アセトン可溶脂需について：アセトン可 溶脂質招よびそれを構成する混合脂肪酸の性質につ いての結果を Table 3 に示す。类た，酸価，不鐱 化物量，混合脂肪酸の平均分子量を用いて算出した アセトン可溶脂質の椯成を Table 4 に示す。アセ トン可溶脂質の沃素価は発腿期亲でいつたん隇少し 次いで漸堌している。哺化価の变化はわずかであ る。このことから不館和脂肪酸部分に，翼択的な消 費が行なかれることが予想される。言から明らかな よ5に，遊離脂肪酸の增加が見られ，特に嘌化後の 增加が著るしい。生体内でのこのように多量の遊離 脂肪酸の存在は疑和しいが，脂肪酸の平均分子量に 大きな変化が見られない点から考克て，多分，粰化 後，Yolk の吸收とともに Embryo の内臟諸器官 の発達により Lipase のために脂肪の分解が盛えに

行なわれるためではなからうか。李たその原因は，燐脂質からのるのも考完られるが，主な原因は中性脂肪 の加水分解によると思和れる。

\section{摘}

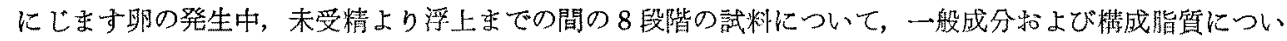
て，その変化を調べた。先の結果，アセトン可溶物質の消費が主として睬化後に示され，アセトン不溶脂質

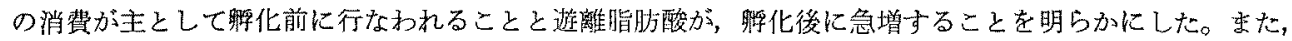
受精より発眼までの間に，不飽和脂肪酸の撰択的な消貿の行なわれることを予想した。

Table 4. Composition of acetone soluble lipids calculated from Acid Value, Moleculer Equivalent and unsaponifiable matter.

\begin{tabular}{c|c|c|c|}
$\begin{array}{c}\text { Sample } \\
\text { No. }\end{array}$ & $\begin{array}{c}\text { Free fatty } \\
\text { acid } \\
(\%)\end{array}$ & $\begin{array}{c}\text { Neutral fat } \\
(\%)\end{array}$ & $\begin{array}{c}\text { Unsap. } \\
\text { matter } \\
(\%)\end{array}$ \\
\hline I & 2.88 & 89.09 & 8.03 \\
II & 2.91 & 89.14 & 7.95 \\
III & 3.17 & 88.97 & 7.86 \\
IV & 3.89 & 88.57 & 7.54 \\
V & 4.73 & 88.18 & 7.09 \\
VI & 7.34 & 85.21 & 7.43 \\
VII & 13.19 & 80.30 & 6.51 \\
VII & 21.85 & 70.92 & 7.23 \\
\hline
\end{tabular}


本研究を行なうにあたり，試料採集にさいし多大の御便宜を与兄られた長野県水産指導所長谷崎正生氏に 感謝の意を表する。

$$
\text { 文献 }
$$

1) J. Ngedham: "Chemical Embryology" Cambridge Univ. Press, 1931.

2) J. BRaCKet: "Chemical Embryology" Intersci. Pnb. 1950.

3) F. R. Hayes and D. M. Ross: Pro. Roy. Soc. B 122, 358 (1936).

4) A. HoliLet and F. R. HAYES: Can. J. Res., D 24, 39 (1946).

5) J. A. Lovern: Biochem. J. 30, 20 (1936).

6) M. Glover, R. A. Morton and D. G. Rosen: Biochem. J. 50, 425 (1952).

7）座間宏一・片田宗男・五十䛜久向：本誌，24，569 (1958).

8) 山村弥六郎・武藤清一郎：東北水研研報 19，171 (1961).

9) W. M. SPERY: "Method of Biochemical Analysis" Vol. II. 83, Intersci. Pub.

10) J. Folch, M. Lees and G. H. Sloanestanley: J. Biol. Chem. 226, 497 (1957).

11) HILDITCH: "Chemical Constitution of Natural Fats" Wiley. New York. 1947.

12) 須山三千三・荻野珍吉：本誌，23，785 (1958). 